\title{
The Codification of Nonprofit Governance - A Comparative Analysis of Swiss and German Nonprofit Governance Codes*
}

\author{
Georg von Schnurbein ${ }^{\dagger}$ \\ and \\ Sabrina Stöckli ${ }^{\ddagger}$ \\ Centre for Philanthropy Studies (CEPS) \\ University of Basel, Switzerland
}

\begin{abstract}
During the last decade, several nonprofit governance codes have emerged in Germany and Switzerland. In contrast to the corporate sector, where one code exists in each country, the nonprofit sector has not unified its initiatives on governance guidelines. The reason for this might be either the missing will to co-operate or significant differences of the code contents - or both. Based on a content analysis of fifteen governance codes from Germany and Switzerland this survey give some insight about the different range of issues and level of detail. Additionally, the influence of the kind of elaborator of the codes is taken into account. The results show that nonprofit governance codes are divergent in terms of range and detailedness. Finally, both aspects are dependent of the kind of producer of the code.
\end{abstract}

Key Words: Nonprofit Governance, Governance Codes, Transparency, Germany, Switzerland

\footnotetext{
* Work in Progress, please do not cite without the authors permission.

${ }^{\dagger}$ Georg von Schnurbein is assistant professor at the Faculty of Economics at the University of Basel (WWZ) and director of the Centre for Philanthropy Studies (CEPS) at the University of Basel, Switzerland.

${ }^{\ddagger}$ Sabrina Stöckli is PhD student and research associate at the Centre for Philanthropy Studies (CEPS) at the University of Basel, Switzerland.
} 


\section{Introduction}

Governance has gained importance in both research and practice in nonprofit management. There is a common understanding that governance is a premise for a better board performance (Carver, 2001; Holland and Jackson, 1998; Preston and Brown, 2004). Attempts in defining nonprofit governance often refer to corporate governance approaches, especially to the agency theory (Fama and Jenson, 1983; Callen, Klein \& Tinkelman, 2003). Following existing corporate governance standards, nonprofit governance addresses mainly legal and fiduciary responsibilities, most likely transparency, effectiveness, and checks and balances (Stone and Ostrower, 2007). However, most definitions do not go beyond the statement that Nonprofit Governance is a set of instruments, measures and mechanisms, which supports the board of an NPO in the process of providing leadership, direction and accountability. In search for a better practicability and standardization, the nonprofit sector soon has followed the profit sector in defining good governance through principles and guidelines, recorded in codes.

Basically, principles of decision making, checks and balances, and decision control in respect to the stakeholder interests are the main features of governance codes (Zimmer and Basic 2007). However, the manifold and divergent stakeholder interests cannot be addressed in a general way. Thus, governance codes serve as a basis of general understanding of governance. The first governance codes were developed in countries with common law like the United Kingdom or the United States and were oriented to corporations. Other countries like Germany or Switzerland followed soon after with their own governance codes for corporations.

Besides, governance codes are made to avoid legal regulations that are stricter, less adjustable, and more bureaucratic (Dawson and Dunn 2006). In contrast to law, one can decide voluntarily to follow soft law regulations like governance codes. Usually, they are based on a comply or explain-rule, e.g. a disrespect of a part of the code is possible but has to be explained. Some codes are published as recommendations with an even lower compliance (Theisen 2003).

The major difference between corporate and nonprofit governance is the question of the owners. While the stakeholders of a company can be structured in a hierarchical way starting with the financial capital owners, a likewise structure cannot be made for nonprofits (Speckbacher 2008). Usually, donors and beneficiaries of nonprofits are not identical, but can both be understood as principals. The former may expect an efficient use of their donations (Fama and Jenson 1983). The latter know best, how the nonprofits can serve them to get by in life (Abzug and Galaskiewicz 2001). This unsolved question has implications on the 
development of governance codes in Germany and Switzerland. As in the corporate sector, several initiatives were started to define general governance guidelines in both countries. While there corporate initiatives were unified to one corporate governance code in each country, there are still several different nonprofit codes co-existing, and there is no sign of coordination.

\section{Literature on Nonprofit Codes}

Neither in the literature nor in practice exists a complete overview of the nonprofit governance codes in Germany and Switzerland. Existing literature concentrates on basic aspects such as the transfer of corporate to nonprofit governance guidelines. (Siebart 2006b, Schwarz and von Schnurbein 2005, Theuvsen 2008).

However, articles comparing different governance codes always refer to a small sample of two to three codes without clarifying the reason of their choice (Dawson and Dunn 2006; Lichtsteiner 2008). In the following section, the most relevant articles comparing governance codes are shortly described.

Dawson and Dunn (2006) examine the appropriateness of the Governance Hub Code and the challenges nonprofit organizations are facing when implementing the code. The authors draw the experience of the corporate Combined code upon. The authors conclude, that the Hub Code is generally valuable as a governance and regulatory tool, but significant aspects, as the extent of constituency remain unclear. Based on their findings the authors specify general requirements for the development and implementation of nonprofit governance codes.

Theuvsen (2008) develops a measuring concept for the operationalization of transparency in nonprofit organizations. The Swiss NPO-Code is then analyzed based on this concept. The author shows that governance codes only focus on a subset of transparency aspects.

Lichtsteiner (2008) compares the Swiss NPO-Code, the Swiss Foundation Code and the Swiss Code of Best Practice for Corporate Governance based on the criteria accountability, general assembly, board, control, and transparency. He shows that the codes feature different levels of detail. Concerning the criteria "control" the author discovers significant differences between the codes.

Siebart (2006b) analyzes if the main subjects of the German corporate code can be transferred into the nonprofit sector. It is argued that basically all subjects are transferrable and that the relevance of the subjects ranges from indifferent (division of leadership and control) to highly 
relevant (dealing with conflicts of interest \& provision of guidelines for accounting and reporting).

Our study is the first attempt to present a complete list of all nonprofit governance codes existing in Germany and Switzerland as a basis for our research. Not included in our list are quality management certificates and donor certificates which are both more oriented to the operative activities of an organization. Whereas governance codes usually address the strategic level of the organization.

Based on a systematic literature analysis with professional journals, organization reports, and open sources, a total list of fifteen codes was generated (table 1). Ten codes come from Germany, five are from Switzerland.

\begin{tabular}{|c|c|c|c|c|c|}
\hline Abbr. & Name of the code & Producer of the code & $\begin{array}{l}\text { Organization } \\
\text { type }\end{array}$ & Year & Country \\
\hline $\begin{array}{l}\text { Arbeits- } \\
\text { hilfen }\end{array}$ & Arbeitshilfen 182 & $\begin{array}{l}\text { Verband der Diözesen } \\
\text { Deutschlands und } \\
\text { Kommission für caritative } \\
\text { Fragen der Deutschen } \\
\text { Bischofskonferenz }\end{array}$ & $\begin{array}{l}\text { central } \\
\text { organization }\end{array}$ & 2004 & DE \\
\hline Diakonie & $\begin{array}{l}\text { Diakonischer Corporate } \\
\text { Governance Kodex }\end{array}$ & $\begin{array}{l}\text { Diakonisches Werk der } \\
\text { Evangelischen Kirche in } \\
\text { Deutschland e. V. }\end{array}$ & $\begin{array}{l}\text { central } \\
\text { organization }\end{array}$ & 2005 & DE \\
\hline SFC & Swiss Foundation Code & $\begin{array}{l}\text { Swiss Foundations - } \\
\text { Verband der Schweizer } \\
\text { Förderstiftungen }\end{array}$ & $\begin{array}{l}\text { umbrella } \\
\text { organization }\end{array}$ & 2005 & $\mathrm{CH}$ \\
\hline GGS & $\begin{array}{l}\text { Grundsätze Guter } \\
\text { Stiftungspraxis }\end{array}$ & $\begin{array}{l}\text { Bundesverband Deutscher } \\
\text { Stiftungen }\end{array}$ & $\begin{array}{l}\text { umbrella } \\
\text { organization }\end{array}$ & 2006 & DE \\
\hline SNC & Swiss NPO-Code & $\begin{array}{l}\text { Konferenz der Präsidentinnen } \\
\text { und Präsidenten grosser } \\
\text { Hilfswerke KPGH }\end{array}$ & $\begin{array}{l}\text { umbrella } \\
\text { organization }\end{array}$ & 2006 & $\mathrm{CH}$ \\
\hline $\begin{array}{l}\text { Kinder- } \\
\text { nothilfe }\end{array}$ & $\begin{array}{l}\text { Diakonischer Corporate } \\
\text { Governance Kodex der } \\
\text { Kindernothilfe e.V. }\end{array}$ & Kindernothilfe e.V. & $\begin{array}{l}\text { single } \\
\text { organization }\end{array}$ & 2007 & DE \\
\hline WBG & $\begin{array}{l}\text { Empfehlung zu guter Führung } \\
\text { (Corporate Governance) von } \\
\text { Wohnbaugenossenschaften }\end{array}$ & $\begin{array}{l}\text { Schweizerischer Verband für } \\
\text { Wohnungswesen (SVW) }\end{array}$ & $\begin{array}{l}\text { umbrella } \\
\text { organization }\end{array}$ & 2007 & $\mathrm{CH}$ \\
\hline STR & $\begin{array}{l}\text { Good Governance Code der } \\
\text { Stiftung für das Tier im Recht }\end{array}$ & Stiftung für das Tier im Recht & $\begin{array}{l}\text { single } \\
\text { organization }\end{array}$ & 2007 & $\mathrm{CH}$ \\
\hline DOSB & $\begin{array}{l}\text { Richtlinien der } \\
\text { Verbandsführung des } \\
\text { Deutschen Olympischen } \\
\text { Sportbundes }\end{array}$ & $\begin{array}{l}\text { Deutscher Olympischer } \\
\text { Sportbund (DOSB) }\end{array}$ & $\begin{array}{l}\text { single } \\
\text { organization }^{1}\end{array}$ & 2007 & DE \\
\hline TCS & $\begin{array}{l}\text { Verhaltenskodex für } \\
\text { Mitglieder der Organe, } \\
\text { Führungskräfte und } \\
\text { Mitarbeitende im TCS }\end{array}$ & Touring Club Schweiz (TCS) & $\begin{array}{l}\text { single } \\
\text { organization }\end{array}$ & 2007 & $\mathrm{CH}$ \\
\hline
\end{tabular}

\footnotetext{
${ }^{1}$ The DOSB is classified as single organization because the code is only addressed to the central organization.
} 


\begin{tabular}{|c|l|l|l|c|c|}
\hline Misereor & $\begin{array}{l}\text { Grundsätze zur Transparenz } \\
\text { Von MISEREOR }\end{array}$ & $\begin{array}{l}\text { Bischöfliches Hilfswerk } \\
\text { MISEREOR e. V. }\end{array}$ & $\begin{array}{l}\text { single } \\
\text { organization }\end{array}$ & 2008 & DE \\
\hline GUL & $\begin{array}{l}\text { Corporate Governance Kodex } \\
- \text { Gute Unternehmensführung } \\
\text { in der Lebenshilfe }\end{array}$ & $\begin{array}{l}\text { Bundesvereinigung } \\
\text { Lebenshilfe für } \\
\text { Menschen mit geistiger } \\
\text { Behinderung e.V. }\end{array}$ & $\begin{array}{l}\text { central } \\
\text { organization }\end{array}$ & 2008 & DE \\
\hline VENRO & VENRO Verhaltenskodex & $\begin{array}{l}\text { Bundesverband } \\
\text { entwicklungspolitischer } \\
\text { Nichtregierungsorganisatione } \\
\text { n e.V. (VENRO) }\end{array}$ & $\begin{array}{l}\text { organization } \\
\text { ombrella }\end{array}$ & 2008 & DE \\
\hline AWO & $\begin{array}{l}\text { AWO Unternehmenskodex } \\
\text { AWO Bundesverband e.V. }\end{array}$ & $\begin{array}{l}\text { central } \\
\text { organization }\end{array}$ & 2008 & DE \\
\hline STGG & $\begin{array}{l}\text { Selbstverpflichtung für mehr } \\
\text { Transparenz und gute } \\
\text { Geschäftsführung }\end{array}$ & $\begin{array}{l}\text { Aktion „Brot für die Welt“ und } \\
\text { Diakonie Katastrophenhilfe }\end{array}$ & $\begin{array}{l}\text { single } \\
\text { organization }{ }^{2}\end{array}$ & 2008 & DE \\
\hline
\end{tabular}

Table 1: Overview of the Swiss and German nonprofit governance codes in chronological order

\section{Research Questions}

As there exist several nonprofit governance codes the question arises, which commonalities and differences can be found? This study concentrates on a content analysis of the existing codes.

The introduction already showed that there is not one general and coherent understanding of governance. Thus, it can be expected that the different codes have different contents and emphases. These differences may be the result of a different level of detail or of a varying range in respect of the issues addressed in the code. Both aspects have a crucial impact on the implementation of a code. If the level of detail is too low, the code might be regarded as shallow. If it is too precise, it will not be adjustable to the special surroundings of one organization. The broadness of issues means that a code can cover all aspects of governance or only a few selected issues. With the content analysis we like to analyze which issues the different codes address and if there are significant differences between the codes.

Research Question 1: How do nonprofit governance codes differ in respect of content and issues addressed?

Usually, governance codes are the result of self regulation. Thus, the acceptance of a code is always dependent on the legitimacy of the producers. In most countries, the corporate codes were developed by practitioners, not state authorities. It is important that the producers know the reality and that they develop reasonable guidelines based on their own experience

\footnotetext{
${ }^{2}$ The organizations are affiliated and belong to the umbrella association Diakonisches Werk der Evangelischen Kirche in Deutschland e.V.
} 
(Dawson and Dunn 2006). As pointed out before, there is a misfit of owners in nonprofit organizations. Thus, it is not unimportant who developed a nonprofit governance code and thereby defined the basic understanding. This study tries to give insight on the question, what consequences have the kind of producer for the content of a nonprofit governance code.

Research Question 2: What influence do the producers have on the content of a code?

\section{Methodology}

The methodology to answer these two research questions is explained in the following section. A major focus is put on the description of the criteria to assess the different codes in order to generate a comprehensible and objective comparison of the codes.

The comparative content analysis is based on the criteria developed by Siebart (2006b) which are chosen because of the multi-dimensionality and their relevance for nonprofits. The criteria are described in the following.

\section{Division of leadership and control}

The division of ownership and control is one of the major reasons of governance problems in corporations and the primary assumption of the agency theory (Berle and Means 1932). In the nonprofit context the division of taking decisions and controlling their implementation is the vital aspect of governance (Alexander and Weiner 1996). However, it is unclear if a total division is necessary or not (Siebart 2006a; Nobbie and Brudney 2003). But it is obvious that a clarification of competencies and accountabilities among different actors is an important factor for an efficient governance structure (Siebart 2006a). Thus, a code should contain requirements for the information of the board, the need for co-operation, and the obligation to participate in the development of strategies (Siebart 2006b).

\section{Definition of clear allocation of competencies}

The division of tasks is a major problem of the organizational structuring in nonprofits. Wrong or unclear allocated competencies lead to inefficiency of management (Schwarz 1996).

The relation between the board and the CEO is the most important governance relation (von Schnurbein 2008). However, this relation is heavily influenced by the fact that it is often not easy to divide the tasks of both actors completely from each other because the tasks of leadership and control cannot be separated totally (Siebart 2006b). The co-existence of volunteers and paid staff leads to a structural conflicts that is driven by interests, power, and prestige (Schütte 2000). The insufficient definition of competencies of these groups leads to 
discrepancies, and further on reduces the transparency and efficiency of an organization. Governance code can help to avoid conflicts if they contain guidelines on the separation and allocation of tasks (Siebart 2006b).

\section{Requirements for risk management}

Avoiding risks and detecting chances is elementary to the strategic management of any company or organization (Heilmair and Witt 2008). However, many nonprofits lack of a structured risk management. Thus, governance codes should contain basic requirements of a risk management in nonprofits (Siebart 2006b).

Dealing with conflicts of interest

Nonprofits are driven by different interests and groups of interests. The board has the obligation to combine the different interests and clarify the general strategy of the organization. However, if diverging interests cannot be aligned, conflicts of interest arise. These are one of the main reasons for governance problems (Hart 1995). Research studies have shown that guideline on how to deal with conflict of interests can ameliorate the work of the board (Holland 2002)

\section{Composition of the board}

The general mission of the nonprofit, the complex goal system, and the participation rights of different stakeholder group lead to a composition of the board that is not only guided by expertise. The composition of the board is driven by several factors, e.g. representation of stakeholder groups, integration of important donors etc. (Siebart 2006b; Siebart 2006a).

However, expertise is a relevant condition for the evaluation of the organization's and the CEO's work. Furthermore, the composition of the board influences the effectiveness and performance of the organization in (Schuhen, 2002, Siciliano, 1996). Thus, basic requirements about the composition of the board should be part of a governance code.

\section{Transparency}

Transparency is important for external stakeholders such as donors or the public to value the performance of the organization and to compare it with social expectations (Theuvsen 2008). Guidelines on transparency are an important aspect of governance codes, because the legitimacy and acceptance of the organization is dependent of the external stakeholders (Siebart 2006b).

Transparency contains different aspects. First, the structural transparency is necessary to offer stakeholders the relevant information in order to participate in decision making. Second, social transparency contains the information behavior of the actors. Finally, process 
transparency shows how fast, clear, and true the information is delivered to the stakeholders by the organization (Theuvsen 2008).

Securing an effective information system

Information is important to evaluate and interpret decision making situations. This function is covered by accounting systems that collect data in a systematic and complete manner and that process the data timely (Schwarz 2006). An effective information system facilitates the exchange between the internal stakeholders and the management level within the organization. (Eschenbach, Horak \& Furtmüller 2007). Through complete information of the directors and the board, information asymmetries can be reduced and abuse of power avoided.

Provision of guidelines for accounting and reporting

The final criteria of nonprofit governance are requirements for accounting and reporting. Most nonprofits are dependent on external public and private funders in order to realize their mission. Thus, the nonprofits are accountable to these donors and have to report on the money spending. Without a consistent accounting an organization cannot give a persuasive report on their operations and how they met the donors' expectations (Theuvsen 2008).

Internally, accounting supports decision making and the definition of future goals and strategies. These two aspects have gained more importance since nonprofits become more and more professional and management driven. Furthermore, basic requirements of accounting are legally regulated (Eschenbach, Horak \& Furtmüller 2007). This contains the nomination of an independent auditor who examines the economic transactions and testifies an adequate accounting. This secures an independent control that is usually not given in the relation of the board and the CEO (Siebart 2006b).

Maybe there are more criteria that can be taken into account in order to analyze nonprofit governance codes, but in our opinion this list covers the most frequently mentioned aspects of governance well. For the content analysis, each criterion was coded with four different levels. The code value "_“ means that the relevant criteria is not included in the code. The code values “+”, “++”, “+++” reflect the elaborateness of the relevant issue in the code. Based on this code system all issues where analyzed in all governance codes. Table one shows as an example, how the coding system works for the criterion “division of leadership and control”.

\begin{tabular}{|c|l|}
\hline \multicolumn{2}{|c|}{ Criterion „Division of leadership and control“ } \\
\hline Code Level & Description \\
\hline- & The subject is not mentioned. \\
\hline+ & The basic principle is named. \\
\hline
\end{tabular}




\begin{tabular}{|c|l|}
\hline++ & The main features of the dualistic model are described. \\
\hline+++ & $\begin{array}{l}\text { The dualistic model is described in detail. The code contains for instance guidelines } \\
\text { on collaboration, the supply of information and the duties of the supervisory and } \\
\text { management board. }\end{array}$ \\
\hline
\end{tabular}

Table 2: Coding system for the criterion „division of leadership and control“

Despite a consequent exertion of the coding system, subjective influences cannot be eliminated totally. Thus, to minimize subjectivity the governance codes where coded independently through two researchers and diverging ratings discussed afterwards.

Further restrictions have to be made due to possible interferences between the criteria chosen. For instance, there is a possible interference of transparency and information system. To reduce overlapping, the criteria where defined narrowly. In the concrete example, transparency is reduced to its external component (transparency to external stakeholders), whereas the information system contains the standardization of information flow within the organization.

Based on the described proceedings and under consideration of the mentioned restrictions, the content analysis led to the results shown in table 3. 
Sabrina Stöckli and Georg von Schnurbein

\begin{tabular}{|c|c|c|c|c|c|c|c|c|}
\hline Code (Abbr.) Criterion & $\begin{array}{l}\text { Division of } \\
\text { leadership and } \\
\text { control }\end{array}$ & $\begin{array}{c}\text { Definition of } \\
\text { clear allocation } \\
\text { of } \\
\text { competencies }\end{array}$ & $\begin{array}{l}\text { Requirements } \\
\text { for risk } \\
\text { management }\end{array}$ & $\begin{array}{l}\text { Dealing with } \\
\text { conflicts of } \\
\text { interest }\end{array}$ & $\begin{array}{l}\text { Composition of } \\
\text { the board }\end{array}$ & Transparency & $\begin{array}{l}\text { Securing an } \\
\text { effective } \\
\text { information } \\
\text { system }\end{array}$ & $\begin{array}{l}\text { Provision of } \\
\text { guidelines for } \\
\text { accounting and } \\
\text { reporting }\end{array}$ \\
\hline Arbeitshilfen 182 (Arbeitshilfen) & + & + & + & +++ & +++ & + & + & + \\
\hline $\begin{array}{l}\text { Diakonischer Corporate Governance } \\
\text { Kodex (Diakonie) }\end{array}$ & +++ & +++ & + & +++ & ++ & - & +++ & + \\
\hline Swiss Foundation Code (SFC) & + & +++ & ++ & +++ & +++ & ++ & + & +++ \\
\hline $\begin{array}{l}\text { Grundsätze Guter Stiftungspraxis } \\
\text { (GGS) }\end{array}$ & + & - & - & ++ & - & ++ & + & + \\
\hline Swiss NPO-Code (SNC) & ++ & +++ & +++ & ++ & ++ & ++ & +++ & ++ \\
\hline $\begin{array}{l}\text { Diakonischer Corporate Governance } \\
\text { Kodex der Kindernothilfe e.V. } \\
\text { (Kindernothilfe) }\end{array}$ & +++ & +++ & + & ++ & + & - & +++ & + \\
\hline $\begin{array}{l}\text { Empfehlung zu guter Führung } \\
\text { (Corporate Governance) von } \\
\text { Wohnbaugenossenschaften (WBG) }\end{array}$ & +++ & ++ & ++ & ++ & ++ & + & ++ & + \\
\hline $\begin{array}{l}\text { Good Governance Code der Stiftung für } \\
\text { das Tier im Recht (STR) }\end{array}$ & ++ & +++ & ++ & ++ & - & ++ & ++ & + \\
\hline $\begin{array}{l}\text { Richtlinien der Verbandsführung des } \\
\text { Deutschen Olympischen Sportbundes } \\
\text { (DOSB) }\end{array}$ & ++ & ++ & - & +++ & - & + & +++ & - \\
\hline $\begin{array}{l}\text { Grundsätze für Corporate Governance } \\
\text { beim TCS (TCS) }\end{array}$ & + & + & + & ++ & +++ & ++ & + & ++ \\
\hline $\begin{array}{l}\text { Grundsätze zur Transparenz von } \\
\text { MISEREOR (Misereor) }\end{array}$ & + & + & + & - & - & +++ & - & ++ \\
\hline $\begin{array}{l}\text { Corporate Governance Kodex - } \\
\text { Gute Unternehmensführung in der } \\
\text { Lebenshilfe (GUL) }\end{array}$ & +++ & +++ & +++ & +++ & ++ & - & +++ & ++ \\
\hline VENRO Verhaltenskodex (VENRO) & ++ & ++ & ++ & + & + & +++ & ++ & +++ \\
\hline AWO Unternehmenskodex (AWO) & +++ & +++ & + & +++ & + & - & ++ & + \\
\hline $\begin{array}{l}\text { Selbstverpflichtung für mehr } \\
\text { Transparenz und gute } \\
\text { Geschäftsführung (STGG) }\end{array}$ & + & + & + & - & - & +++ & - & ++ \\
\hline
\end{tabular}

Table 3: Results of the content analysis 


\section{Results}

The results of the content analysis presented in table 3 show that the governance codes have different profiles in regard of the eight criteria. The exceptions are the two codes Misereor and Diakonie which show the same coding profile. First, we are now going to present the result addressing the range of issues and the level of detail in all the criteria. Second, we are going to take a closer look at the producers of the code.

The range of issues refers to the number of criteria that are covered by a certain governance code. The analyzed code can be situated on a continuum starting form very narrow to very wide. Six codes have a wide range of issues covering all issues of the analysis. On example for such a code is the Swiss Foundation Code (SFC) which contains guidelines to the eight criteria and additionally addresses further issues such as spending policy, project selection, and asset management (Sprecher, Egger \& Janssen 2008). Besides the SFC, the following codes cover a comparable wide range of issues: the Swiss NPO Code (SNC), the code WBG, and the code TCS from Switzerland; the Arbeitshilfen and the code VENRO from Germany.

At the other end of the continuum there are four codes that cover only five issues. For instance, the codes Misereor and STGG do not mention guidelines on the composition of the board, on the information system, or how to deal with conflicts of interest. Additionally, the codes GGS and DOSB have a rather low range of issues, as well.

However, the range of issues only gives information, if an issue is addressed in a governance code or not. But there cannot be made any conclusion, how an issue is elaborated in the code. Thus, with the second aspect of the level of detail we look at the elaborateness of each governance code. After coding the detailedness of all governance codes in each issue, we counted the number of issues valued with “+++” for each code.

The code GUL has the highest level of detail with five issues ranked “+++”. This code explains each issue very thoroughly. For instance, in the context of conflicts of interest the code does not only address individual conflicts of interest of board members, directors, or collaborators. Moreover, it addresses institutional conflicts of interest, as well. In this section, the role of the organization as agency and consultancy for other organizations is clarified. The different conflicts of interests are illustrated with practical examples in order to ameliorate the understanding of the code. Besides the GUL, the SFC and the code Diakonie with four issues ranked “+++” offer a high level of detail.

A low level of detail has the code GGS that is not ranked “+++” in any issue. This code contains only general guidelines to the different issues without mentioning clear requirements for the 
practice. This leaves a lot of space for interpretation. For instance, it is not clarified, which governance actor is responsible for special tasks and issues. Next to the code GGS, there are the codes Misereor, STGG, WBG, STR, and TCS that have only one issue ranked “+++”.

In order to better analyze the content of each codes, we looked at the correlation of range of issues and level of detail (table 4). The radius of the circles at the nodes of the matrix show the number of governance codes that are at the same node. Based on this diagram we developed three different clusters of governance codes: codes with basic principles and low range of issues; codes with special focus and wide range of issues; and detailed codes with wide range of issues.

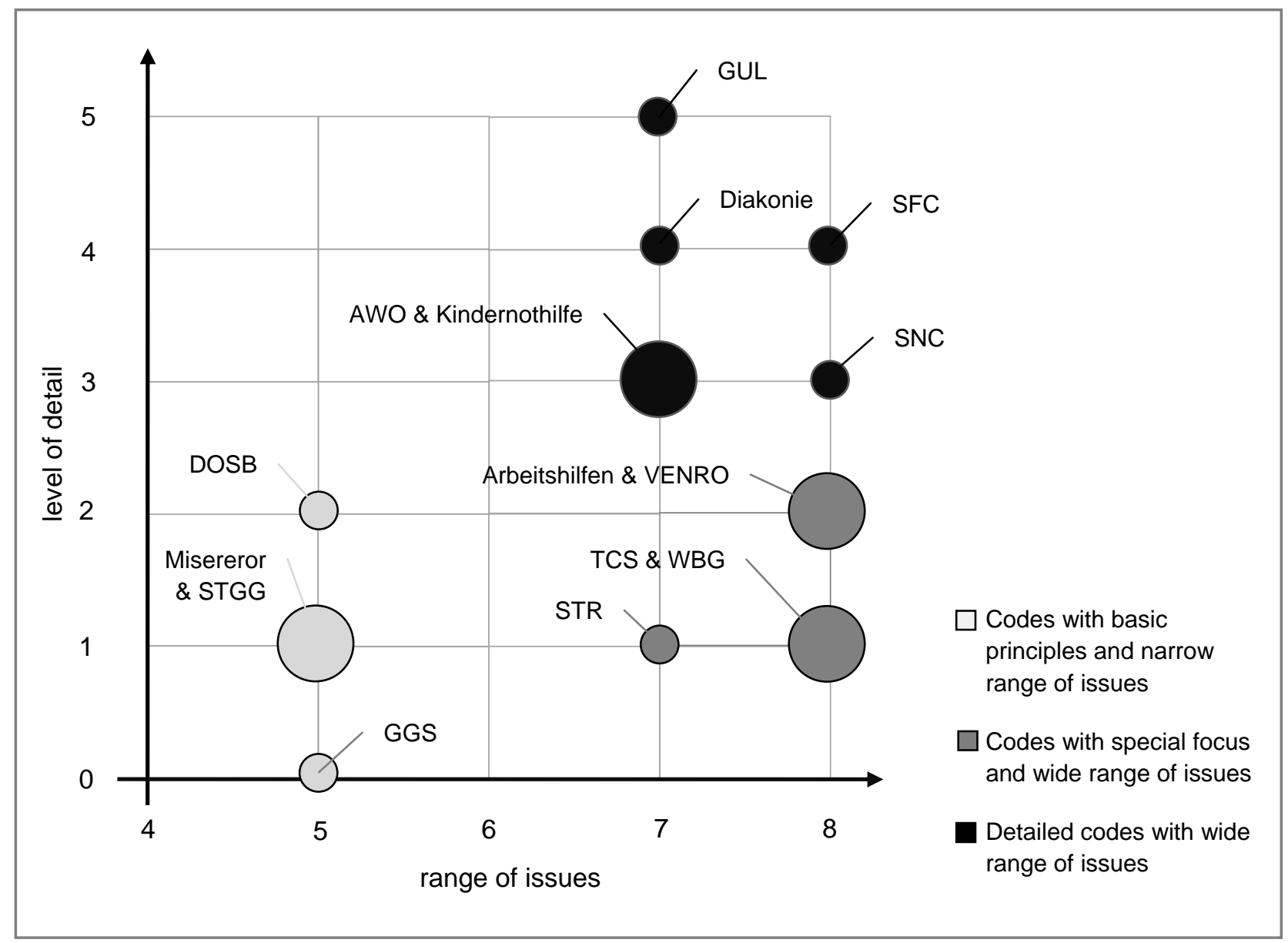

Table 4: Correlation of range of issues and level of detail

\section{Codes with basic principles and narrow range of issues}

The codes in this cluster are form by a low level of details and a narrow range of issues. They offer basic principles to a selected number of issues and leave space for adjustments and interpretations. Some of the codes have one or two issues that are described in more detail, for instance transparency or conflicts of interest. The codes in this cluster transmit the general ideas 
and principles of governance, but do not offer detailed information, how these principles can be realized in practice.

\section{Codes with special focus and wide range of issues}

This cluster contains governance codes that cover a wide range of issues. Just like the codes in the first cluster they focus on some selected issues that are covered in greater detail. These focus issues vary from one code to another and seem to reflect special challenges that are faced by the organizations addressed by the code. For instance, the code VENRO is very precise on requirements of transparency and accounting. The target group of this code is development aid organizations that rely heavily on private fundraising. Thus, transparency and accounting are very important issues for these organizations. The codes in this cluster show a strong orientation towards the expectations and the needs of their target groups.

\section{Detailed codes with wide range of issues}

Finally, the last cluster covers the codes with a wide range of issues that are covered in great detail. These codes were ranked "+++" in at least three issues in our analysis. Especially the code GUL and the Swiss Foundation Code offer a lot of detailed information on each governance issue. They go beyond listing expected requirements and give additional examples and explanation how the requirements should be realized in practice. However, the code GUL and the SFC are both presented as recommendations with no compliance rule for the organizations addressed. Through the way the codes in this cluster are elaborated, they are the closest to common corporate governance codes. This broad setup gives them a reputation that goes beyond their target group.

To conclude, the previous section gives some information to answer research question one. By analyzing the content of the governance codes in regard of the two criteria the range of issues and the level of detail, we have shown that there is a great variety among the nonprofit governance codes. Three different clusters were defined in order to classify the governance codes. Nonprofit governance codes offer divergent information on governance. Some present the basic principles, others give detailed information on focused subjects, and some others function as soft law with a large scope. 
In order to determine and classify the producers of the codes in our analysis, we differentiated them according to their network character as single organization, central organization, and umbrella organization (table 1). Single organizations are formally independent and have elaborated a code that is only addressed to their own organization. Central organizations are the centre or national unit of several other mostly independent organizations. The central organization is hierarchically superior to the other organization and the code addresses all of these organizations. Finally, umbrella organizations are central or national organizations, where other independent organizations of one industry can become member on a voluntary basis.

\section{Single organizations}

Six codes in our analysis where elaborated by single organizations. These codes usually refer strongly to the specific structures and circumstances of the single organization. For instance, the code STR is strongly oriented on the legal structure of the organization that is a foundation. The specific tasks and requirements of the board, the directors, and other governance actors are highlighted throughout the code. The codes Misereor and STGG highlight the transparency towards external stakeholders, most importantly their donors. These organizations are specialized on fundraising for church-related organizations. Finally, the code DOSB put the emphasis on conflicts of interest. This code was elaborated after the vice president of the organization came under criticism because of his activities as consultant parallel to his position in the organization (Inacker 2008). The rules on how to implement this code are highly related to the special structure of the single organization. The definition of governance according to the requirements of the single organization and the high level of individualization results in a narrow coverage of governance issues. The codes Misereor and STGG give detailed information on transparency, but at the same time they offer no guidelines on conflicts of interest, composition of the board, or the information system. Other governance issues with a stronger internal orientation such as division of leadership and control or definition of competencies are covered superficially. In another example, the code Kindernothilfe, we find a reverse situation. Here, internal issues such as information system, definition of competencies, and division of leadership and control are highly elaborated. But the transparency towards external stakeholders is not mentioned, at all.

The solitude of the organizations endangers a limited perspective and understanding of governance that is only reflected by the organization's own situation. 


\section{Central organizations}

Four codes of the sample are produced by central organizations. All of these codes have a high level of detail and cover a wide range of issues. Thus, they all belong to the third cluster. One reason for this consistent totality of these codes is the fact that they have to contain governance guidelines for different legal forms, e.g. associations and foundations. This given situation requires detailed and differentiated information in various cases. For instance, the supervision of members in associations does not exist in foundations, because they have no members. Thus, foundations are supervised by state authorities. These legal basics have to be respected in the governance codes of central organizations (and umbrella organizations, as well).

Although the codes are very detailed, they are not very individualized. The codes are formulated in a general and open manner. They avoid giving clear figures, e.g. number of board members, because they have to respect the different structures of their subunits. The competencies and responsibility to put the codes in to practice is delegated to the subunits. Thus, each subunit has to adjust the code to its own situation. Usually, the code does not contain guidelines for the implementation.

Another typical characteristic of the codes of central organization is the definition of the target group through quantitative limits, e.g. amount of earnings, number of fulltime collaborators. These criteria should protect small subunits that might be overburdened with the complexity of the code. Usually, the code is binding for the organizations above the limit and should be respected by does below the limit. As the central unit is hierarchical superior, it can constrain the subunits to comply with the code. On exception of this high compliance is the code GUL, which is only presented as recommendations.

\section{Umbrella organizations}

In contrast to the codes of central organizations, the codes elaborated by umbrella organizations have a high individualized character. This can be explained with the fact that these codes are adjusted to the special requirements of the target organizations. Three of the five codes in this group have a high level of individualization. For instance, the Swiss Foundation Code targets only grant making foundations, and refers to the special conditions of these organizations, only. In the code VENRO, one chapter deals with the communication of the organizations, especially the public relations and fundraising communication. The chapter contains special requirements for this issue and lists communication means that are reasonable for fundraising organizations. 
Another characteristic of these codes is their wide range of issues. Four of the five codes cover all eight issues and go even beyond. In this respect, there is a clear difference to governance codes of single organizations that cover only selected issues.

The development of the codes in umbrella organizations is done through a participative process that includes the member organizations. Thus, the implementation takes longer than in central organizations that do not consequently include their subunits. It seems that the umbrella organizations put a high emphasis on legitimating their code through the participative and open process. The code VENRO emphasizes collaborative implementation of the code and a continuous development of the code in the future.

By highlighting the strong support among opinion leaders and important members, the acceptance of the code is fostered. It animates the members to implement the code in their own organization. This is necessary because the umbrella organization have less influence on their members than central organizations on their subunits. Thus, the implementation of the code has to be realized by acceptance.

This leads to the conclusion that the codes of umbrella organizations cover a wide range of issues and display a high degree of individualization. The development of the code is the result of a participative process that is described in the code.

However, this classification refers completely only to three of the five codes from umbrella organizations. The codes GGS and WBG do not fit into this description. Especially, they show a lower range of issues and a lower degree of individualization. The difference between these codes and the ones mentioned before can be explained with the logic of collective action (Olson 2004).

Olson (2004) states that individual and collective reality are not always consistent, because for some group members, it is more rational to maximize their own utility. Group size influences the impact of the degree of consistency. Olson differentiates between privileged, medium-sized, and latent groups. Both, the Bundesverband Deutscher Stiftungen (3’000 members) as producer of the code GGS and the Schweizerische Verband für Wohnungswesen (987 members) as producer of the code WBG can be classified as latent groups. Within latent groups, the individual member is not influential any more. This circumstance raises the attempt for individual utility maximization. Thus, a collective good such as a governance code has to be covered by a common interest of the latent group. If the common interest is missing, the members try to maximize their own utility. As a consequence, the umbrella organization has to put up positive or negative incentives to realize a collective action of the members. 
If the members maximize their own interests in the process of the elaboration of a governance code, it will be difficult to find solid compromises. Thus, the result of this process is the least common denominator.

It can be stated that the basic character of the codes GGS and WBG is based on three aspects, according to the logic of common action:

- $\quad$ size of the organization

- missing common interest in the issue of governance

- missing positive or negative incentives of the umbrella organization.

Based on the method and results of this study, we can only analyze the size of the organization. But no comment can be made about the two additional arguments.

Answering research question two, we state that the kind of the producers does have an influence on the content of nonprofit governance codes. A major influential fact is the type of the organization. Table 5 concludes the specific content features of single, central, and umbrella organizations. Additionally, the twofold group of codes produced by umbrella organizations showed that there might be other criteria that influence the content of a code, as well. Next to the size of the organization this could be structures of interest or incentives.

\begin{tabular}{|c|c|}
\hline Organization type & Typical code characteristics \\
\hline Single organization & $\begin{array}{l}\text { - } \quad \text { narrow range of issues } \\
\text { - } \quad \text { high level of individualization }\end{array}$ \\
\hline Central organization & $\begin{array}{l}\text { - } \text { wide range of issues } \\
\text { - } \text { low level individualization } \\
\text { - high level of detail } \\
\text { - } \text { high level of bindingness } \\
\text { - definition of the target group through quantitative limits }\end{array}$ \\
\hline Umbrella organization & $\begin{array}{l}\text { - } \quad \text { high level of individualization } \\
\text { - } \quad \text { wide range of issues } \\
\text { - development of the codes through a participative process }\end{array}$ \\
\hline
\end{tabular}

Table 5: Typical code characteristics according to the network character of the producer

\section{Conclusion}

This paper focused on the analysis of the content and the producers of nonprofit governance codes in Germany and Switzerland. For the first time, a complete list of all nonprofit governance 
codes in the two countries was conducted as a basis for this study. Former studies used a smaller sample of governance codes without clarifying the reasons for the selection.

The content analysis was based on eight governance issues taken from the literature in order to allow a structured and comparable analysis of the different codes. Based on the results we answered two research questions on the content and the producers of nonprofit governance codes. First, the analysis has shown that the content of governance codes is divergent in respect of the range of issues and the level of detailed information. Thus, three clusters were developed in order to classify the codes. Second, the influence of the kind of producers was investigated. Codes of single organizations tend to be less complete and are strongly focussed on a few relevant issues. While codes of central organizations and umbrella organizations are both wide in the range of issues, they differ significantly in terms of individualization. Codes of central organizations are written in a general manner, addressing many different types of organizations. Codes of umbrella organizations are much more oriented on the specific situation of their member organizations. However, there are some codes of umbrella organizations that show a lower profile.

Based on these findings we draw some conclusions for practice and further research. In general, the codes analyzed for this study had a very high degree of elaboration and reflected a professional understanding of nonprofit governance. Organizations thinking about implementing governance guidelines in their organizations should be aware of the fact that the content of different governance codes vary extremely. Thus, they have to make the choice either to accept an existing governance code or to establish one on their own. In the former case, the organization should proof who developed the code. In the latter case, the organization should try to find other organizations to participate in order to realize a more consistent governance code. Umbrella organizations have to put the emphasis on the participation process of developing the code in order to reduce the influence of individual interests.

This leads to our implications for further research. Better knowledge is necessary about the implementation of the governance codes. As most of the codes are not too old, it might be too early to stress the question, what impact governance codes have on the organizational performance of nonprofits. Another interesting issue for ongoing research is the analysis of further influence factors on the content of governance besides the kind of the producers. As the number of governance codes is small, it is difficult to conduct a quantitative survey on this topic. However, it would be interesting to test the acceptance of the codes and the participation process of development among a larger group of organizations that complies with a governance code. 
To conclude, this survey has added some insight for a better understanding of the development of nonprofit governance codes. This might help for the future to ameliorate the implementation and acceptance of governance codes.

\section{References}

Abzug, R. and Galaskiewicz, J. (2001), 'Nonprofit Boards: Crucibles of Expertise or Symbols of Local Identities?’, in: Nonrprofit and Voluntary Sector Quarterly, Vol. 30, No. 1, pp 51-73

Alexander, J. A., and Weiner, B. J. (1996), 'The Adoption of the Corporate Governance Model by Nonprofit Organizations’, in: Nonprofit Management \& Leadership, Vol. 8, Nr. 3, pp 223242

AWO Bundesverband e.V. (ed.) (2008), ,AWO Unternehmenskodex‘, Berlin

Bachert, R. (2005), ,Corporate Governance in Nonprofit-Organisationen', in: Ruter, R., Sahr, K., and Waldersee, Georg G. (eds.): Public Corporate Governance. Ein Kodex für öffentliche Unternehemen, Wiesbaden: Gabler, pp 195-218

Berle, A., and Means, G. (1932), 'The Modern Corporation and Private Property’, New York: Transaction Publishers

Bischöfliches Hilfswerk MISEREOR e.V. (ed.) (2008), ,Grundsätze zur Transparenz von Misereor', Aachen

Böckli, P. (2002), ,Harte Stellen im Soft Law‘. in: Der Schweizer Treuhänder, 2002, No. 11, pp $1-12$

Bundesministerium für Justiz (ed.) (2002), ,Gesetz zur weiteren Reform des Aktien- und Bilanzrechts, zu Transparenz und Publizität‘, Berlin

Bundesverband Deutscher Stiftungen (ed.) (2006), ,Grundsätze Guter Stiftungspraxis‘, Berlin

Bundesverband Deutscher Stiftungen (ed.) (2009), ,Jahrbuch des Bundesverbandes Deutscher Stiftungen', Berlin

Bundesverband entwicklungspolitischer Nichtregierungsorganisationen e.V. (ed.) (2008), ,VENRO Verhaltenskodex‘, Bonn

Bundesvereinigung Lebenshilfe für Menschen mit geistiger Behinderung e.V. (ed.) (2008), 'Corporate Governance Kodex. Gute Unternehmensführung in der Lebenshilfe', Marburg

Cadbury, Sir A. (1992), 'Report of the Committee on The Financial Aspects of Corporate Governance’, London

Callen, J. L., Klein, A., and Tinkelman, D. (2003), 'Board Composition, Committees, and Organizational Efficiency: The Case of Nonprofits', in: Nonprofit and Voluntary Sector Quarterly, Vol. 32, No. 4, pp 493-520

Carver, J. (2001), ‘A Theory of Governing the Public's Business: Redesigning the Jobs of Boards, Councils, and Commissions’, in: Public Management Review, Vol. 3, No. 1, pp 5372

Cromme, G. (2005), 'Corporate Governance in Germany and the German Corporate Governance Code’, in: Corporate Governance, Vol. 13, No. 3 , pp 362-367 
Dawson, I., and Dunn, A. (2006), 'Governance Codes of Practice in the Not-for-Profit Sector', in: Corporate Governance, Vol. 13, No. 1, pp 33-42

Deutscher Olympischer Sportbund DOSB (ed.) (2007), ,Richtlinien der Verbandsführung des Deutschen Olympischen Sportbundes', Frankfurt

Diakonisches Werk der Evangelischen Kirche in Deutschland e.V. (ed.) (2005), ,Diakonischer Corporate Governance Kodex‘, Stuttgart

Diakonisches Werk der Evangelischen Kirche in Deutschland e.V. (ed.) (2008), ,Selbstverpflichtung für mehr Transparenz und gute Geschäftsführung‘, Stuttgart

economiesuisse (ed.) (2002), 'Swiss Code of Best Practice for Corporate Governance’, Zürich

Egger, P., von Schnurbein, G., and Stöckli, S. (2009), ,Stichwortverzeichnis’, Basel‘

Eschenbach, R, and Horak, C (2007), ,Rechnungswesen und Controlling، in NPOs, in: Badelt, C. et al. (eds): Handbuch der Nonprofit Organisationen. Strukturen und Management, $4^{\text {th }}$ edition, Stuttgart: Badelt, pp 275-298

European Foundation Center (ed.) (2009), 'Codes and Principles of Good Practice: A European Overview’. www.efc.be/codex/eucodes.htm, 06.07.2009

Fama, E., and Jensen, M. (1983), 'Separation of Ownership and Control', in: Journal of Law and Economics, Vol. 26, pp 301-325

Hart, O. (1995), 'Corporate Governance: Some Theory and Implications', in: The Economic Journal, Vol. 105, No. 430, pp 678-689

Heilmair, A., and Witt, D. (2008), ,Risikomanagement in Verbänden - Status quo und Ausblick', in: Schauer, R. et al. (eds): Steuerung und Kontrolle in Nonprofit-Organisationen, Linz: Trauner, pp 231-252

Holland, T., and Jackson, D.K. (1998), 'Strengthening Board Performance', in: Nonprofit Management \& Leadership, Vol. 9, No. 2, pp 121-134

Holland, T. (2002), 'Board Accountability: Lessons from the Field', in: Nonprofit Management \& Leadership, Vol. 12, No. 4, pp 409-428

Inacker, T. (2008), ,Grenzen nicht überschritten', http://www.wiwo.de/politik/grenzen-nichtueberschritten-274317, 06.07.2009

Huff, A. S. (2009), 'Designing Research for Publication', Thousand Oaks: Sage Publications

Kindernothilfe e.V. (ed.) (2007), ,Diakonischer Corporate Governance Kodex der Kindernothilfe‘ e.V., Duisburg

Konferenz der Präsidentinnen und Präsidenten grosser Hilfswerke KPGH (ed.) (2006), ,Swiss NPO-Code‘, o. O. 2006

Kornmeier, M. (2007), ,Wissenschaftstheorie und wissenschaftliches Arbeiten‘, Heidelberg; Physica-Verlag

Lichtsteiner, H. (2008), ,Entwicklungsstand der Governance im Nonprofit-Sektor der Schweiz‘, en: Schauer, R. et al. (eds): Steuerung und Kontrolle in Nonprofit-Organisationen, Linz: Trauner, pp 455-478

Marti, M. (2002), ,Corporate Governance in der Schweiz - Vergleich mit den Regeln in Deutschland'.Deutsch-Schweizerischen Juristenvereinigung (ed.): Sonderbeilage zu den Mitteilungen zum deutsch-schweizerischen Rechtsverkehr 
Nobbie, P. D., and Brudney, J. L. (2003), ‘Testing the Implementation, Board Performance, and Organizational Effectiveness of the Policy Governance Model in Nonprofit Boards of Directors’, in: Nonrprofit and Voluntary Sector Quarterly, Vol. 32, No. 4, pp 571-595

OECD (ed.) (2001), 'OECD Principles of Corporate Governance’, Paris

Olson, M. (2004), ,Die Logik des kollektiven Handelns‘, $5^{\text {th }}$ edition, Tübingen: Mohr Siebeck

Purtschert, R. (2004), ,Good Corporate Governance: Ansatz für Verbände und weitere NPO?‘, in: Verbandsmanagement, No. 3, pp 6-17

Preston, J. B., and Brown, W. A. (2004), 'Commitment and Performance of Nonprofit Board Members’, in: Nonprofit Management \& Leadership, Vol. 15, No. 12, pp 221-238

Salamon, L. and Geller, S. (2005), 'Nonprofit Governance and Accountability’. The John Hopkins Nonprofit Listening Post Project. Communiqué No.4.

www.ccss.jhu.edu/pdfs/LP_Communiques/LP_Communique4_GovernanceAcct_2005.pdf, 30.07.09

Schuhen, A. (2002), ,Nonprofit Governance in der Freien Wohlfahrtspflege‘, Baden-Baden: Nomos

Schwarz, P. (1996), ,Management in Nonprofit-Organisationen`, $2^{\text {nd }}$ edition, Bern: Haupt

Schwarz, P. (2006), ,Management-Prozesse und -Systeme in Nonprofit-Organisationen`, Bern: Haupt

Schwarz, P., Purtschert, R., and Giroud, C. (2002), ,Das Freiburger Management-Modell für Nonprofit-Organisationen', $4^{\text {th }}$ edition, Bern: Haupt

Schwarz, P., and von Schnurbein, Georg (2005), ,Gemeinsamkeiten und strukturelle Unterschiede der Corporate und Nonprofit Governance', in: Zeitschrift für öffentliche und gemeinwirtschaftliche Unternehmen, Vol. 24, No. 4, pp 358-375

Schweizerischer Verband für Wohnungswesen SVW (ed.) (2007), ,Empfehlung zu guter Führung (Corporate Governance) von Wohnbaugenossenschaften`, Zürich

Schweizerischer Verband für Wohnungswesen SVW (ed.) (2009), ‘Geschäftsbericht 2008', Zürich

Sicililano, J. (1996), 'The Relationship of Board Member Diversity to Organizational Performance', in: Journal of Business Ethics, Vol. 15, No. 12, pp 1313-1320

Siebart, P. (2006a), 'Corporate Governance von Nonprofit-Organisationen: Ausgewählte Aspekte der Organisation und Führung‘, Bern: Haupt

Siebart, P. (2006b), ,Ein Kodex für Nonprofit-Organisationen?‘, in: Birkholz, K. et al. (eds): Public Management: Eine neue Generation in Wissenschaft und Praxis, Potsdam: Universitätsverlag, pp 221-236

Speckbbacher, G. (2008), 'Nonprofit Versus Corporate Governance: An Economic Approach’, in: Nonprofit Management \& Leadership, Vol. 18, No. 3, pp 295-320

Sprecher, T., Egger, P., and Janssen, M. (2008), 'Swiss Foundation Code 2009. Grundsätze und Empfehlungen zur Gründung und Führung von Förderstiftungen`, $2^{\text {nd }}$ edition, Basel: Helbing Lichtenhahn

Stiftung für das Tier im Recht (ed.) (2007), ,Good Governance der Stiftung für das Tier im Recht', Bern 
Stone, M.M., and Ostrower, F. (2007), 'Acting in the Public Interest? Another Look at Research on Nonprofit Governance’, in: Nonprofit and Voluntary Sector Quarterly, Vol. 36, No. 3, pp 416-438

Theisen, M. R. (2003), 'Herausforderung Corporate Governance’, in: Die Betriebswirtschaft, Vol. 63, No. 4, pp 441-461

Theuvsen, L. (2008), ,Transparenz von Nonprofit-Organisationen‘, in: Schauer, R. et al. (2008): Steuerung und Kontrolle in Nonprofit-Organisationen, Linz: Trauner, pp 37-71

Touring Club Schweiz TCS (ed.) (2007), ,Verhaltenskodex für Mitglieder der Organe, Führungskräfte und Mitarbeitende im TCS‘, Vernier

Verband der Diözesen Deutschlands (ed.) (2004), ,Arbeitshilfen 182‘, Bonn

von Schnurbein, Georg (2008), ,Nonprofit Governance in Verbänden. Theorie und Umsetzung am Beispiel von Schweizer Wirtschaftsverbänden‘, Bern

Witt, P. (2000), ,Grundprobleme der Corporate Governance und international unterschiedliche Lösungsansätze‘, in: Nippa, M., Petzold, K., and Kürsten, W. (eds): Grundprobleme der Corporate Governance: Herausforderungen und Lösungsansätze, Heidelberg, pp 41-72

Zimmer, A., and Basic, A. (2008), ,Governance in und mit Nonprofit-Organisationen‘, in: Schauer, R. et al. (eds): Steuerung und Kontrolle in Nonprofit-Organisationen, Linz: Trauner, pp 135-156 